\title{
Domestic Violence Against Women in Bangladesh: A Comparative Study on the Perception of Educated and Non-Educated Class.
}

\author{
Md. Abul Hasama ${ }^{*}$, Md. Shahidul Islam b \\ a Lecturer, Sociology, Department of Humanities, Primeasia University, Banani, Dhaka-1213, Bangladesh. \\ b Research Associate, BISR (Bangladesh Institute of Social Research) Trust, Bangladesh. Email: shahidulsoc@gmail.com. \\ ${ }^{*}$ Corresponding author's email address:hasam.sustsoc53@gmail.com
}

\section{A R T I C L E I N F O}

Received: 14-06-2016

Accepted: 21-06-2016

Available online: 29-06-2016

Keywords:

Domestic Violence against Women; Dowry; Perception ; Educated and Non-educated class; Bangladesh.

JEL Classification:

J12; J16; M12; C83; D80; A220

\begin{abstract}
A B S T R A C T
This paper tries to analyze perception of educated and non-educated class about domestic violence against women .To knows the objectives, descriptive research design has been followed. Sample size is found out by applying systematic random sampling used. For quantitative method, survey method has been used and for qualitative method, case study method has been used. Here, the Likert scaling (1-to-5 rating scale) has been applied for some variables. Data has been analyzed by using SPSS, Univariate and bivariate has been done. For hypotheses testing, F- test used to test the degree to which two or more groups vary or differ in an experiment.

The findings suggest that the perception about domestic violence against women was difference between educated and non-educated class. Most of the respondents (50.4\%) think that violence means physical and mental torture but only $8 \%$ thinks it means physical, mental and verbal abuse. Again, $14.4 \%$ respondents view in that violence means doing anything against one will. $95.2 \%$ respondents say that there in difference in the forms of violence between and in laws house when only $4.8 \%$ find no difference. Only $27 \%$ educated and $9.8 \%$ non-educated respondents opined that dowry is the main reason of domestic violence, $2.7 \%$ educated and $5.9 \%$ non-educated told that women are the enemies of women, $18.9 \%$ educated and $11.8 \%$ non-educated told that only because of poverty domestic violence takes place. $21.6 \%$ educated and $25.5 \%$ noneducated respondents think that for women's suppression tradition and custom is responsible.

This study may help to government to take appropriate policy to stop the domestic violence against women.
\end{abstract}

This is an open access article under the terms of the Creative Commons Attribution License 4.0, which allows use, distribution and reproduction in any medium, provided the original work is properly cited.

DOI: http://dx.doi.org/10.18533/rss.v1i6.43

ISSN: 2378-8569 (Print), 2378- 8550 (Online)

\subsection{Introduction}

Generally any activity committed by someone with a view to hurting anybody physically is called violence. Violence is a worldwide concept. To some extent, every individual is familiar with this term, with its impacts. An individual, either man or woman, may face violence at any time. But it in most cases, women are the main victims of violence (Adams and et al, 2008). Violence differs from time to time, place to place and people to people in varying degrees. Whenever it is happened, either inside the house or outside of it, women violence is gender discrimination based violence (Adams and et al, 2008). Gender violence is a daily and often deadly 
matter of life for millions of women and girls around the world. The actual and human costs of violence are tremendous. Violence devastates lives, fractures communities and in inhibits development.

In Bangladesh, violence against women is occurring in almost every aspect of women's lives. So, it is a serious threat to overall development and progress of the country (Parvin and et al, 2016). Women are thrashed in their homes, raped in their communities, tortured, sexually assaulted and even raped by the state police. The pervasive nature of violence against women in Bangladesh has been a major concern for government, donors, NGOs and other civil society groups in the country for many year's (Parvin and et al, 2016) Various international organizations are also working to ensure women's human rights and for fight violence against women in the society.

But the index of violence is increasing. In our country women face multiple forms of oppressions. They don't have equal access to food, health and education. But they have to carry the double burden of households and productive activities (Mannan, 2003). For the few years, various types of violence against women such as rape incidents, acid throwing, abduction, murder and physical torture were increased alarmingly. Meanwhile, in our country particularly in rural areas dowry incidents and physical torture and murder for dowry were common phenomena (Parvin and et al, 2016). Just before some years, the UNFPA Report mentioned that this region is the first ranking in the world in wife beating and Bangladesh got itself at the top of the index. It is evident that domestic violence is rampant in all strata of the society naturally and usually, women are the first violence of this violence (Parvin and et al, 2016).

Bangladesh society is a patriarchal society; domestic violence against women is significant in our country. Women of all strata are vulnerable to maltreatment and abuse at the hands of husbands, in-laws and other family members. Despite its increasing trend, domestic violence is viewed as a personal matter that should be resolved privately within the family (Parvin and et al, 2016). Bangladesh Mahila Parishad(BMP) reported that in our country domestic violence is not still considered as a violence of human rights of women. Patriarchal social and family structure and culture are the main causes of this attitude towards domestic violence (Kay, 2008). For this reason the condition of women in Bangladesh is vulnerable.

Violence committed by family members within the family environment is the most serious of all types of violence. All the same time, the closed family structure makes it possible for the aggressor to repeat the violence (Jahan\& Islam, 1997). Women are subjected to domestic violence by male members, in-laws and even by other female members. It is occurred not only in poor or illiterate families but also in rich and literate families. In some communities, female babies and girl children are neglected. Dowry is the main cause of harassment of young brides in thousands of reported cases and at times it leads to death (Sahay, 1998:5). So, violence has no class, no caste, no religion and it is a universal phenomenon (Bhuiyan). It exists in all classes, i. e. upper, middle and lower classes in various forms.

In our society, women of upper class don't reveal their vulnerable situation because of their social status and they themselves try to solve the problem privately. Women of middle class do not try to file case and feel hesitation to disclose it to others because they are very much concerned about their self-respect. The people of middle class do believe in vanity and in social values and they think that it is their pride. On the other hand, women from lower class never try to reveal it and don't tell it to others and they treat it as a normal matter. There may have two reasons namely-(i) Ignorance of the existing laws and punishment for violence, (ii) Their socio-economic position.

So, for a clear understanding of the problems it is needed to know the nature and extent of the problem. In this context, it is our concern to find out what are the views of educate and non-educated people regarding domestic violence. Thus, the present study would try to know the perception of educated and non-educated people on domestic violence against women. Though government has formulated many laws regarding domestic violence, it exists in every society. So, in this study it is tried to explore the nature of domestic violence and also tried to explore the perceptions regarding domestic violence that will help the government to take proper step to review the existing laws and also to implement them property.

\subsection{Objectives of the study}

The research has a broad objective that is-

(1) To know and analyze the perception of educated and non-educated class about domestic violence against women.

This broad objective has been split into several specific objectives which are as follows:

(i)To assess the socio-economic condition of the educated and non-educated class respondents. 
(ii)To know the nature of domestic violence against women.

(iii)To know the causes of domestic violence against women.

(vi)To make a comparison between educated class's views about violence perpetuated in family environment and that of non-educated class.

\subsection{Review of literature}

Akanda \& Shamim (1985) showed that family quarrels was one of the major causes of death both in rural and urban areas. In village area 22 percent wives died for dowry and in urban area it was 10 percent. Mostly the younger age groups were victimized just after they are married or after some years of married life. Though there was a dowry related law, The Dowry Prohibition Act 1980, the Act cannot act as a hinder against dowry.

Halim (1995) summarized a terrified picture of the conditions of women throughout the world. According to Dr. Radhika Coomaraswamy, the UN special Rapporteur on violence against women and Srilankan civil rights activist, a rape occurs every minute in South Africa and every six minute in the U.S. A, 39 percent of the Vietnamese boat people were raped by sea pirates, 12000 women were raped an brutalized in former Yugoslavia in 1992, 98 percent women in Pakistan are beaten up by their husbands, 80 percent in Chile experience violence. In a Bombay hospital 95 percent of fetuses identified as female were aborted. Every year some 8000 to 10000 women are brought from Thailand to Japan for prostitution. In Bangladesh, malnutrition is three times higher among girls than among boys. He mentioned that many people don't consider violence as serious and oppressive. Wife beating or subjecting female spouse to mental torture has been going on in different societies including Bangladesh. But in our country, many female spouses might consider these oppressive behavior patterns as normal part of everyday life. They have been suffering from various types of either physical violence or mental torture or both at different times in their short or long conjugal. The data show that $71.31 \%$ women were beaten by their male partners with hand or other body parts while $64.34 \%$ told that their husbands use different dangerous objects like cross-bar of doors, cooking materials etc. to hurt them. Meanwhile, $11.47 \%$ percent reported that they were even beaten by in-laws i.e. mothers-in-law, sisters-in-law etc.

Jahan\& Islam (1997) they found that over the last two decades, violence against women has been considered as the most visible social issues in Bangladesh. In our country, psychological violence among married couple is not considered seriously and remains unreported. UNICEF representative Rolf C. Carriere noted that one out of four Children women is subject to physical violence at home and one out of three suffers psychological aggression. The law in Eqaudor treats violence against women as a natural phenomenon rather than as a crime. In the USA, every hour sixteen women confront rapists and a women is raped every six minutes. Three to four million women face battering every year and every eighteen seconds a women is beaten. In Canada, on out of four women is assaulted at some point in their lives and one and a half of these before the age of 17. In France, 95\% of the victims of violence are women and $51 \%$ of them at the hands of their husbands.

Naved and Persson (2010) examined the relationship between dowry and wife abuse in rural Bangladesh. They found that dowry demand in marriage increase the wife abuse but this scenario is lower while there is no dowry demand at the time of marriage. They also found an interesting result that payment of dowry did not reduce the wife abuse but the demand of the dowry increased day by day.

Naved \& Persson (2005) explored the factors that related to domestic violence against women in Bangladesh. They found that dowry and history of abuse husband's fathers are associated with spousal violence at home. They also revealed that women participation in credits groups increased the risk of women abuse.

Vander Endeand et al. (2015) examined the relationship between income and intimate partner violence (IPV) against women in Bangladesh at both household and community level. They found that lower income of household was associated with women's risk of experiencing IPV but low-income household was not associated with women's risk of experiencing IPV.

\section{$2.0 \quad$ Methodology}

\subsection{Research design}

In this study, descriptive research design has been followed so that it would be able to know and analyze the perception of educated and non-educated class about domestic violence against women through personal interview as well as case study. 
In this study both quantitative and qualitative method has been followed. For quantitative method, survey method has been used and for qualitative method, case study method has been used.

\subsection{Timeframe in which the study is being carried out}

This is a Cross-Sectional Study because this study accomplished at a single point of time in Sylhetcity on August '15-May '2016.Data has been collected during October-December of the same year. Therefore,

\section{$2.4 \quad$ Research site}

Firstly, the study area Sylhet City has been selected purposively. Later,to find out educated respondents, some important universities and college of the study area that provide honors and master degree have been selected as the field of the study and also to find out the non-educated respondents, Ward No.1o under Akhaliathana which are divided into seven blocks has been selected as the field of the study.

\section{$2.5 \quad$ Institutions and ward familiarities}

The institutions are as follow:

Shahjalal University of Science and Technology (SUST),Sylhet International University(SU), Metropolitan University(MU),Leading University (LU),M.C College(MCC),Madan Mohan College (MMC),Sylhet Govt. Women's college(SGWC).

The blocks under ward no.10 are as follow:

Modina market centre(block no.1),Kazipara (block no.2),North Kazipara(block no.3), Pathantola(block no.4), North bagbari(block no.5),South bagbari(block no.6), Bagbariregion (block no.7)

\subsection{Rational/importance of selecting the study area}

As the present research area, above institutions among Sylhet Metropolitan City are used. Because domestic violence against women occurs available in this city like other cities or areas of the country. In Sylhet, dowry system is existed in different forms comparable to any other parts of the country. It is given in the names of gift but it is common for every bride's family to guilt to the bridegroom's family. As a result, whoever is unable to give dowry has to face many types of violence like battering, murder, abuse, deprivation of food, confinement, threats of reprisals etc. In the study area, another powerful evidence of domestic violence is forced marriage and it is also common in this region.

\section{$2.7 \quad$ Population of the study}

The total 437 married person of above mentioned institutions and ward no.10 are selected as the population of the study. Married persons are selected as the research population because married persons usually face the most violence than single persons. Here, those teachers are selected who belong to the institutions. Here the number of married teacher is 328 and the number of non-educated persons is 109.These non-educated persons are those persons who are married, daily laborer or unemployment and belong to age interval 30-40 years old due to shorten the population. These populations are collected from the adjacent institutions' registered office and voter's list.

\subsection{Sampling frame}

There are total 827 holding teachers in seven institution and 9027 holding voters in ward no.10 and there are total 328 married teachers in seven institutions and 109 non-educated married voters (age interval 30-40) in ward no.10. Here 437 married teachers and non-educated married voters is the sampling frame of this study.

\section{$2.9 \quad$ Sampling}

In this study, the stratified random sampling method is used. Systematic random sampling is used when several areas are selected as the research area. In this study, several institutions and vote collection's wards of Sylhet Metropolitan City are considered. For this reason, stratifies random sampling has been used so that sample size can represent the all population of all institutions and blocks. 
The present study, the formula is given by Cochran is used for making a sample size

$$
\text { Formula } n=\frac{\frac{t^{2} p q}{d^{2}}}{1+\frac{1}{N}\left(\frac{t^{2} p q}{d^{2}}-1\right)} \text { (Source: Cochran, 1977:75) }
$$

For comparison of perception on domestic violence against women and laws regarding punishment between educated and non-educated respondents, it is necessary to draw minimum number of teacher (sample size) from each of the group, Therefore, the sample is determined by using following formula for educated and noneducated class separate. Since, in this study, several institutions and voting sub-words has been considered, stratified random sampling with proportion allocation is used to select sample teachers from each of the institutions and respondents from each voting blocks under ward no.10. Here, d sampling error was (0.10) or $10 \%$ and proportion of respondents who have better perception was $(p)=0.5$. Sample size for educated class was 74 and non-educated was 51.

Since, in this study, several institutions and voting sub-words has been considered, Systematic random sampling with proportion allocation is used to select sample teachers from each of the institutions and respondents from each voting blocks under ward no.10. Here following formula is used:

$\mathrm{nt}=\frac{\mathrm{n}}{\mathrm{N} \times \mathrm{Nt}}$

\subsection{Variable of the study}

The variable of the study is divided into two parts:

Perception: Understanding, Sensual knowledge, Interpretation, Observation, Response, Attitude

Domestic Violence: Dowry murder, Wife battering, Deprivation of food, Reproductive control/coercion, Confinement, Forced married, Threats of reprisals etc.

\subsection{Technique of data collection}

In this study, interview schedule has been used for survey and interview guide has been used for case study. Interview schedule and interview guide has been written in English and Bengali version. That means methodological triangulation (Sample, Survey, and case study) has been followed. Firstly the information has been collected by using a structured questionnaire on 33 variables from 125 respondents through sample survey method. Closed-ended, open-ended and dichotomous questions have been set up in the structured questionnaire and information has been collected through face-to-face interviews. For some of variables, Likert Scaling has been followed in the structured questionnaire .These variables has been rated on a 1-to-5 rating scale where: $1=$ Strongly disagree, $2=$ Disagree, $3=$ Undecided, $4=$ Agree and $5=$ Strongly agree. Further, a guide questionnaire on 5 interview guide has been used for case study to find out in-depth understanding of the respondents about domestic violence against women.

\subsection{Limitations of data collection}

In this study, these limitations have been faced during data collection-In a primary record data collection is a troublesome task. In the present study, various institutions are considered as the field of study. So, to collect data from those institutions official rules had to follow. Besides this, as the respondents are teachers and they are busy with their academic tasks, so it is not possible to get them in a free mood to co-operative with the responder. For this reason, the present researcher had to go to these institutions frequently. Moreover, these institutions are located in different areas in the city. On the contrary, the non-educated respondents would not want to give information easily and they said that they have no knowledge about the research and also they would consider the research as a fault. Again, since many respondents thought the present study in related to their own family life, they didn't try to give information for the first time. In this regard, the researcher had to make it understandable to them that it is not about their family life but about the whole society and they how to only give their opinion about it. But when they understand that confidentiality will be maintained them they regarded to co-operate with the researcher and gave information.

\subsection{Technique and statistical tools of data analysis}


The Collected quantitative information from primary source has been analyzed by statistical tools. In this regard, The Statistical Program for Social Sciences (SPSS) has been used. Here univariate and bivariate analysis i.e. percentage and frequency table, cross table, F-test (for hypothesis test) has been used as the statistical tools to analysis the data. Again, according to procedure of Likert Scaling on five rating scale for some of variables, firstly a total score for each respondents has been found out and then average scale values has been found out by substracing the low judges (bottom 25\%) from high (top 25\%) judges. As a result, it would be possible to find out Discriminative Power (DP) out for each variable. To represent qualitative information several case studies has been made. To maintain the confidentiality instead of real name of each respondent pseudonym has been used in the case study .And to enrich the present study secondary data have been collected from various books, journals, articles, website, research studies etc.

\section{$3.0 \quad$ Result}

\subsection{Univariate analysis}

\begin{tabular}{|c|c|c|c|c|c|}
\hline \multicolumn{6}{|c|}{ Table 1: Socio-economic information of the respondents } \\
\hline Variables & Frequency & Percent & Variables & Frequency & Percent \\
\hline Years of age & & & Religion & & \\
\hline $26-30$ & 29 & 23.2 & Islam & 97 & $77.6 \%$ \\
\hline 31-35 & 35 & 28.0 & Hindu & 28 & $22.4 \%$ \\
\hline $36-40$ & 23 & 18.4 & Total & 125 & $100 \%$ \\
\hline $41-45$ & 14 & 11.2 & Family Types & & \\
\hline $46-50$ & 6 & 4.8 & Nuclear & 88 & $70.4 \%$ \\
\hline $51-55$ & 15 & 12.0 & Joint & 37 & $29.6 \%$ \\
\hline $56-60$ & 2 & 1.6 & total & 125 & 100.0 \\
\hline $61-65$ & 1 & .8 & Profession & & \\
\hline Total & 125 & 100.0 & Lecturer & 20 & $16 \%$ \\
\hline Class of respondent & & & Assistant Professor & 22 & 17.6 \\
\hline Educated & 74 & 59.2 & Associate Professor & 28 & $22.4 \%$ \\
\hline Non-educated & 51 & 40.8 & Daily laborer Or other & 51 & $44 \%$ \\
\hline Total & 125 & 100.0 & Total & 125 & 100.0 \\
\hline \multicolumn{3}{|c|}{ Educational qualification of the respondent } & Month of conjugal life & & \\
\hline $\mathrm{Ph} . \mathrm{D}$ & 11 & 8.8 & $0-48$ & 48 & $38.4 \%$ \\
\hline Mp.hil & 5 & 4.0 & $49-97$ & 20 & $16.0 \%$ \\
\hline MS & 10 & 8.0 & $98-146$ & 19 & $15.2 \%$ \\
\hline Masters & 45 & 36.0 & 147-195 & 23 & $18.4 \%$ \\
\hline Honors & 3 & 2.4 & $>195$ month & 23 & $18.4 \%$ \\
\hline Non- educated & 51 & 40.8 & No. of household member & & \\
\hline Total & 125 & 100.0 & $0-3$ & 43 & $34.4 \%$ \\
\hline Income & & & $4-7$ & 67 & $53.6 \%$ \\
\hline 3000-9999 & 51 & 40.8 & Greater than or equal 8 & 15 & $12 \%$ \\
\hline 10000-19999 & 43 & 34.4 & Total & 125 & $100.0 \%$ \\
\hline 20000-29999 & 20 & 16.0 & & & \\
\hline 30000-39999 & 5 & 4.0 & & & \\
\hline 40000-59999 & 5 & 4.0 & & & \\
\hline Greater than or equal to 60000 & 1 & 0.8 & & & \\
\hline Total & 125 & 100.0 & & & \\
\hline
\end{tabular}

In the26-30 years age group 23.2\% respondents are included, on the 31-35 years groups the percentage is $28.0 \%$. But from the next group the percentage is decreasing. Among the total respondents male respondents are $68.0 \%$ and female are $32 \%$. Among the total respondents only $8.8 \%$ holds $\mathrm{PhD}, 4.0 \%$ holds $\mathrm{M}$ Phil, $8 \%$ holds MS, $36.0 \%$ hold masters, $2.4 \%$ honors and $40.8 \%$ respondents hold no education.

In regarding income, 40.8\% respondents are included in 3000-9999 categories but in the highest category it is also very low. But most of the respondents are included in the lowest category but 3000 and 9999 that is most of the respondents are middle income group. In regarding religious view, most of the respondents are Muslims $77.6 \%$ and only $22.4 \%$ respondents are Hindu. Most of the respondent $70.4 \%$ are from nuclear family and $29.6 \%$ respondents are come from joint family.

About 44\% respondents are day laborer and rest is involved in teaching occupation. Majority 38.4\% respondent's conjugal life is between 0 to 48 weeks. Majority respondent have household member between 4-7 member and only $12 \%$ respondents' household member is more than 8 members. 
Table 2: Domestic violence against women related perception according to educated and non-educated class Variables

Domestic violence means

Physical or mental torture

Physical and mental torture

Physical, mental and verbal torture

To do something against one wills

Avoidance and ignorance

Total

\section{Causes of domestic violence}

Difference in opinion

Establishment of domination

Dowry

Patriarchy

Difference in perception

Enmity of women versus women

Poverty

Establishment of domination and dowry

Establishment of domination $\mathrm{n}$ and difference in opinion

Establishment of domination and difference in opinion and poverty

Others

Total

\section{Murder for dowry}

Agree/strongly agree

Disagree/strongly disagree

Total

\section{Confinement}

Agree/Strongly

Disagree/Strongly disagree total

\section{Threats of Reprisal}

Agree/Strongly

Disagree/Strongly disagree

Total

\section{Reproductive control}

Agree/strongly agree

Disagree/strongly disagree

Total

\section{Tradition and custom}

Agree/Strongly

Disagree/Strongly disagree

Total

Consider violence as a normal matter

Agree/Strongly

Disagree/Strongly disagree total

$\begin{array}{rr}\text { educated } \\ \mathrm{n} & \% \\ 2 & 3.9 \% \\ 36 & 70.6 \% \\ 2 & 3.9 \% \\ 5 & 9.8 \% \\ 6 & 11.8 \% \\ 51 & 100.0 \%\end{array}$

\begin{tabular}{rrrr}
\multicolumn{2}{r}{ Non-educated } & & Total \\
\hline 8 & $10.8 \%$ & $\mathrm{n}$ & $\%$ \\
27 & $36.5 \%$ & 10 & $8.0 \%$ \\
8 & $10.8 \%$ & 63 & $50.4 \%$ \\
13 & $17.6 \%$ & 10 & $8.0 \%$ \\
18 & $24.3 \%$ & 18 & $14.4 \%$ \\
74 & $100.0 \%$ & 24 & $19.2 \%$ \\
8 & $10.8 \%$ & 125 & $100.0 \%$
\end{tabular}

3

1

\section{2}

7

4

(1)

2

1

9

3

$74 \quad 100.0 \%$

$50 \quad 67.6 \%$

$24 \quad 32.4 \%$

$74 \quad 100.0 \%$

$42 \quad 58.8 \%$

$32 \quad 43.2 \%$

$74 \quad 100.0 \%$

$48 \quad 64.9 \%$

$26 \quad 35.1 \%$

$74 \quad 100.0 \%$

$6 \quad 21.6 \%$

$58 \quad 74.4 \%$

$74 \quad 100.0 \%$

16

\section{$21.6 \%$}

$78.4 \%$ $100 \%$

$\%$

$\begin{array}{rrrr}2 & 3.9 \% & 5 & 4.0 \\ 3 & 5.9 \% & 4 & 3.2 \% \\ 5 & 9.8 \% & 7 & 5.6 \% \\ 3 & 5.9 \% & 7 & 5.6 \% \\ 2 & 3.9 \% & 6 & 4.8 \% \\ 3 & 5.9 \% & 5 & 4.0 \% \\ 6 & 11.8 \% & 20 & 16.0 \% \\ 8 & 15.7 \% & 17 & 13.6 \\ & & & \\ 2 & 3.9 \% & 5 & 4.0 \% \\ & & & \\ 17 & 33.3 \% & 43 & 34.4 \% \\ & & & \\ 0 & & 3 & 2.4 \% \\ 51 & 100.0 \% & 125 & 100.0 \%\end{array}$

$3 \quad 5.9 \% \quad 15 \quad 12.0 \%$

$\begin{array}{llll}48 & 94.17 \% & 110 & 88.0 \%\end{array}$

$51 \quad 100.0 \% \quad 125 \quad 100.0 \%$

$39 \quad 64.7 \% \quad 83 \quad 66.4 \%$

$18 \quad 35.3 \% \quad 42 \quad 33.6 \%$

$51 \quad 100.0 \% \quad 125 \quad 100.0 \%$

$23 \quad 45.1 \% \quad 65 \quad 52.0 \%$

$28 \quad 54.9 \% \quad 60 \quad 48.0 \%$

$51 \quad 100.0 \% \quad 125 \quad 100.0 \%$

$\begin{array}{rrrr}16 & 31 . \% & 64 & 51.2 \% \\ 35 & 68.6 \% & 61 & 48.8 \% \\ 51 & 100.0 \% & 125 & 100.0 \%\end{array}$

$\begin{array}{rrrr}13 & 25.5 \% & 29 & 29.2 \% \\ 38 & 74.5 \% & 96 & 76.8 \% \\ 51 & 100.0 \% & 125 & 100.0 \% \\ & & & \\ 16 & 31.4 \% & 32 & 25.8 \% \\ 35 & 68.6 \% & 93 & 74.4 \% \\ 51 & 100 \% & 125 & 100 \%\end{array}$




\begin{tabular}{lrrrrrr}
\hline Conflict between husband and wife & & & & & & \\
Agree/Strongly & 72 & $97.3 \%$ & 51 & $100.0 \%$ & 123 & $98.4 \%$ \\
Disagree/Strongly disagree & 2 & $2.7 \%$ & 0 & $00.0 \%$ & 2 & $1.6 \%$ \\
Total & 74 & $100.0 \%$ & 51 & $100.0 \%$ & 125 & $100 \%$ \\
\hline
\end{tabular}

About $10.8 \%$ educated respondents told that violence means physical or mental torture whereas only 3.9\% noneducated respondents' think such information. But most of the respondents told that violence means physical and mental torture such as $10.6 \%$ non-educated and $76.6 \%$ non-educated gave this kind of information. According to $17.6 \%$ educated and $9.8 \%$ non-educated respondents, violence means to do something against one wills. Simultaneously, violence means avoidance and ignorance according to $24.3 \%$ non- educated and $11.8 \%$ educated respondents.

About 2.7\% educated and only 9.8\% non-educated respondents opined that dowry is the main reason of domestic violence, $2.7 \%$ educated and 5.9\% non-educated told that women are the enemies of women, $18.9 \%$ educated and $11.8 \%$ non-educated told that only because of poverty domestic violence takes place. But most of the respondents (educated $35.1 \%$ and non-educated 33.17\%) mentioned not a single cause but because of three factors women face violence in the family that are difference in opinion, women are enemies of women and poverty

About $16.2 \%$ educated and $5.9 \%$ non-educated respondents agree that in family environment women are murdered only for dowry. According to them various types of domestic violence are confinement (32.4\% educated, non-educated 35.3\%), threat of reprisal (educated $43.2 \%$ and non-educated 54.9\%), reproductive control (35.1\% educated, $68.6 \%$ non-educated), and other types (educated $23 \%$, non-educated $17.6 \%$ ). So, in our country dowry murder happens frequently.

$21.6 \%$ educated and $25.5 \%$ non-educated respondents think that for women's suppression tradition and custom is responsible. Among the total respondents of educated (72) 97.3\% acknowledge that in conjugal life conflict exist between husband and wife and only $2.7 \%$ ignore it. On the other hand, the non-educated respondents $21.6 \%$ and $31.4 \%$ report that conflict between husband and wife is a common matter and it may occur for various reasons.

Table 3:Perception/view on various types of causes of violence according to educated and non-educated class

Variable

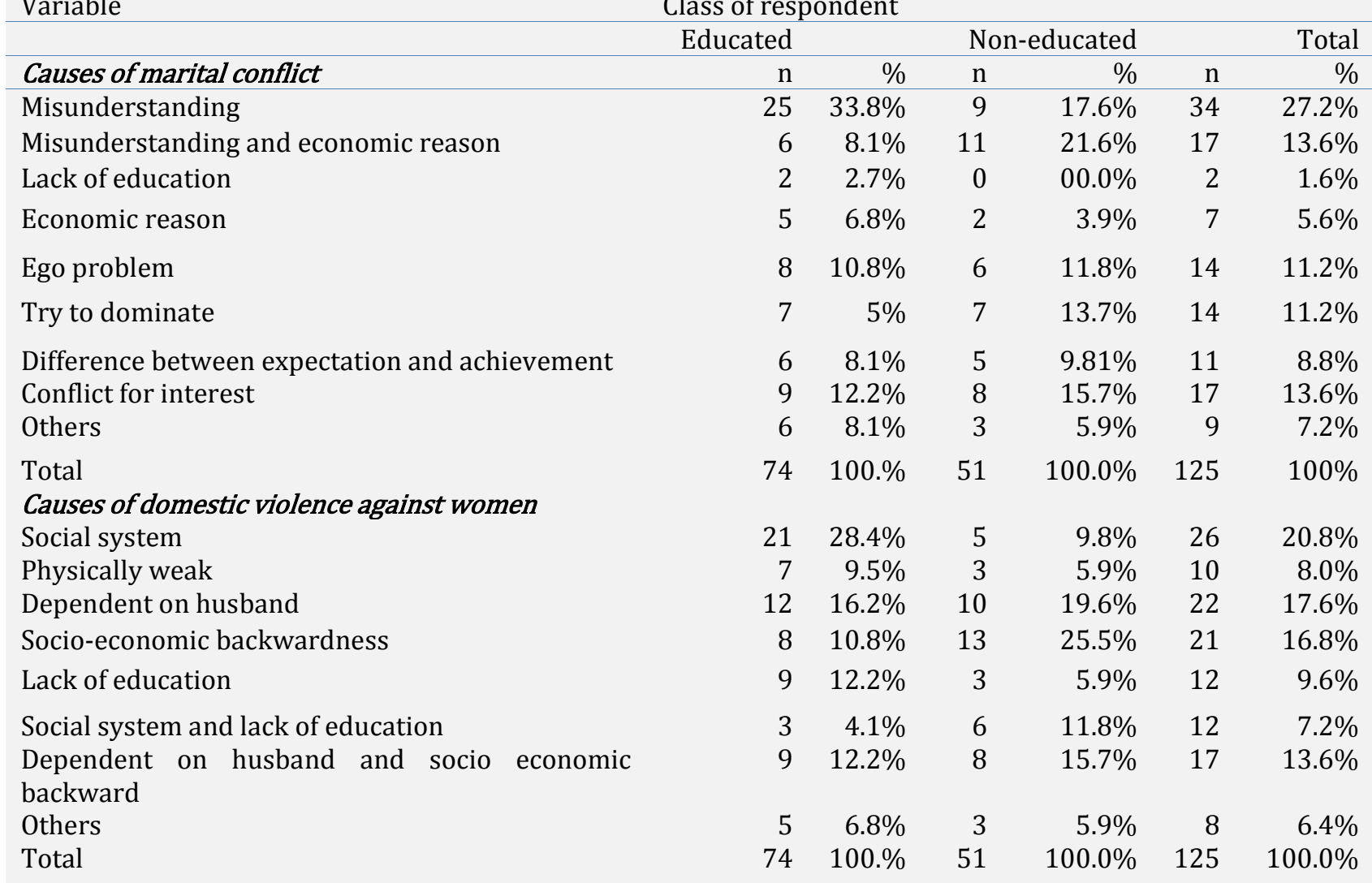

Difference between natal and in-laws house violence against women 


\begin{tabular}{|c|c|c|c|c|c|c|}
\hline Agree/strongly Agree & 68 & $91.9 \%$ & 51 & $100.0 \%$ & 119 & $95.2 \%$ \\
\hline Disagree/strongly disagree & 6 & $8.1 \%$ & 0 & $00.0 \%$ & 6 & $4.8 \%$ \\
\hline Total & 74 & $100 . \%$ & 51 & $100.0 \%$ & 125 & $100.0 \%$ \\
\hline \multicolumn{7}{|c|}{ View on the reason of violence against women due to dowry } \\
\hline Husband's financial condition & 16 & $21.6 \%$ & 10 & $19.6 \%$ & 26 & $20.8 \%$ \\
\hline Mentality and values & 7 & $9.5 \%$ & 6 & $11.8 \%$ & 13 & $10.4 \%$ \\
\hline Family tradition & 3 & $4.1 \%$ & 2 & $3.9 \%$ & 5 & $4.0 \%$ \\
\hline Existing custom & 9 & $12.2 \%$ & 8 & $15.7 \%$ & 17 & $13.6 \%$ \\
\hline Lack of education & 12 & $16.2 \%$ & 5 & $9.8 \%$ & 17 & $13.6 \%$ \\
\hline Mentality, values and tradition & 12 & $16.2 \%$ & 12 & $23.5 \%$ & 24 & $10.2 \%$ \\
\hline Family tradition and values & 5 & $6.8 \%$ & 4 & $7.8 \%$ & 9 & $7.2 \%$ \\
\hline Others & 10 & $13.5 \%$ & 4 & $7.8 \%$ & 9 & $7.2 \%$ \\
\hline Total & 74 & $100 . \%$ & 51 & $100.0 \%$ & 125 & $100.0 \%$ \\
\hline \multicolumn{7}{|l|}{ View on threats of reprisals to women } \\
\hline Blamable and crime & 36 & $48.6 \%$ & 32 & $62.7 \%$ & 68 & $54.4 \%$ \\
\hline Men mentality & 18 & $24.3 \%$ & 11 & $21.6 \%$ & 29 & $23.2 \%$ \\
\hline Cowardice & 12 & $16.2 \%$ & 7 & $13.7 \%$ & 19 & $15.2 \%$ \\
\hline Others & 8 & $10.8 \%$ & 1 & $2.0 \%$ & 9 & $1.2 \%$ \\
\hline Total & 74 & $100 . \%$ & 51 & $100.0 \%$ & 125 & $100.0 \%$ \\
\hline \multicolumn{7}{|c|}{ View on change in pattern of domestic violence against women from mother to own generation } \\
\hline $\begin{array}{l}\text { Decreasing physical torture but increasing mental } \\
\text { torture }\end{array}$ & 19 & $25.7 \%$ & 19 & $37.3 \%$ & 38 & $30.4 \%$ \\
\hline Increasing dowry related violence & 5 & $6.8 \%$ & 4 & $7.8 \%$ & 9 & $7.2 \%$ \\
\hline $\begin{array}{l}\text { Acid violence was not existed before but it } \\
\text { frequently happens now }\end{array}$ & 2 & $2.7 \%$ & 4 & $7.8 \%$ & 6 & $4.8 \%$ \\
\hline Decreasing violence & 26 & $35.1 \%$ & 5 & $9.8 \%$ & 31 & $24.8 \%$ \\
\hline $\begin{array}{l}\text { Did not decreasing violence but changed in } \\
\text { different forms }\end{array}$ & 17 & $23.0 \%$ & 15 & $29.4 \%$ & 32 & $25.6 \%$ \\
\hline Others & 5 & $6.8 \%$ & 4 & $7.8 \%$ & 9 & $7.2 \%$ \\
\hline Total & 74 & 100.0 & 51 & $100.0 \%$ & 125 & $100.0 \%$ \\
\hline \multicolumn{7}{|l|}{ Men want to control his wife in marital conflict } \\
\hline Agree/strongly agree & 65 & $87.8 \%$ & 49 & $96.1 \%$ & 114 & $91.2 \%$ \\
\hline Disagree/strongly disagree & 9 & $12.2 \%$ & 2 & $3.9 \%$ & 11 & $8.8 \%$ \\
\hline Total & 74 & $100 . \%$ & 51 & $100.0 \%$ & 125 & $100.0 \%$ \\
\hline \multicolumn{7}{|l|}{ Controlling women's using wealth/property } \\
\hline Agree/strongly agree & 41 & $55.4 \%$ & 35 & $68.6 \%$ & 76 & $60.8 \%$ \\
\hline Disagree/strongly disagree & 33 & $44.6 \%$ & 16 & $31.4 \%$ & 49 & $39.2 \%$ \\
\hline Total & 74 & $100 . \%$ & 51 & $100.0 \%$ & 125 & $100.0 \%$ \\
\hline \multicolumn{7}{|l|}{ Threat of bringing second wife to women } \\
\hline Agree/strongly agree & 32 & $45.1 \%$ & 33 & $66.0 \%$ & 65 & $53.7 \%$ \\
\hline Disagree/strongly disagree & 38 & $53.5 \%$ & 17 & $34.0 \%$ & 55 & $45.5 \%$ \\
\hline Undecided & 1 & $1.4 \%$ & 0 & $0 \%$ & 1 & $.8 \%$ \\
\hline Total & 74 & $100 . \%$ & 51 & $100.0 \%$ & 125 & $100.0 \%$ \\
\hline
\end{tabular}

In the case of reason in marital conflict most of the educated respondents give opinion that misunderstanding is the main cause of this conflict( educated 33.8\%,non-educated17.6\%), both misunderstanding and economic reason(educated8.1\%, non-educated $21.6 \%$ ), lack of education( educated $2.7 \%$, non-educated $0 \%$ ), economic reason(educated $6.8 \%$, non-educated $3.9 \%$ ), ego problem(educated $10.8 \%$, non-educated $11.8 \%$ ) of husband and wife for which conflict arises between them, try to dominate( educated 5\%, non-educated $13.7 \%$ ).Another cause is different between expectation and achievement(educated $8.1 \%$, non-educated $9.81 \%),(12.2 \%$ educated and $15.7 \%$ non- educated) respondents mention the cause of conflict for interest and other reasons (educated8.1\% \& non-educated5.9\%)

Domestic violence against women takes place for various reasons such as social system (educated $28.4 \%$, noneducated 9.8\%), physically weak (educated 9.5\%, non-educated 5.9\%), dependent in husband (educated $16.2 \%$, non-educated 19.6\%), socio-economic backwardness (educated 10.4\%, non-educated $25.5 \%$ ) etc. Lack of education (educated 12.2\%, non-educated5.9\%), both of social system and lack of education (educated 4.1\%, non-educated 11.8\%) But commonly both educated and non-educated mention that dependent on husband and 
socio-economic backward is the significant cause of domestic violence against women (educated $12.2 \%$, noneducated $15.7 \%)$.

91.9\% educated and $100 \%$ non-educated respondents view that violence against women is seen in both natal and in-laws house but their forms are different. Only $8.1 \%$ educated don't find any difference in the dorms of violence in both the house. These are a significant association at $10 \%$ confidence level.

Most of the respondents said that husband's financial condition (educated 21.6\%, non-educated 19.6\%), mentality and values (educated9.5\%, non-educated $11.8 \%$ ), ), family tradition (educated $4.1 \%$, non-educated $3.9 \%$ ), existing custom (educated12.2\%,non-educated 15.7\%)), lack of education ( educated 16.2\%, noneducated 9.8\%), mentality, values and tradition(educated $16.2 \%$, non-educated 23.5\%), family tradition and values(educated 6.8\%,non-educated 7.8\%)are the main cause of dowry related violence against women.

About fifty percent educated respondents (48.6\%) label threats of reprisals as a blamable and crime whereas $62.7 \%$ non-educated respondents think so. Again $24.3 \%$ educated and $21.6 \%$ non-educated consider them as men mentality. On the contrary, $16.2 \%$ educated and $13.7 \%$ non-educated respondents treat them as cowardice whoever gives threat to women.

Pattern of domestic violence from mother to own generation is changed. The present study got various finding about the issue. Such as respondents thinks physical torture is decreasing but increasing mental torture(educated $25.5 \%$, non-educated $37.3 \%$ ), increasing dowry related violence now a days(educated $6.8 \%$, non-educated $7.8 \%$ ), acid violence was not existed before but it frequently happens now (educated $2.7 \%$, noneducated 7.8\%), decreasing violence in present( educated 35.1\%, non-educated 9.8\%) but some of respondents think that violence did not decrease but changed in different forms( educated 23\%, non-educated 29.4\%)

According to $87.8 \%$ educated respondents in case of marital conflict men want to control their wives whereas $96.1 \%$ non-educated respondents think so. Only $12.2 \%$ educated and $3.9 \%$ non-educated respondents don't think so.

Again, most of the respondents commented that men control not only on the body women but also on their using wealth (educated 55.4\%, non-educated 68.6\%). Further $44.6 \%$ educated and 31.4\% non-educated respondents are disagreed or strongly disagreed regarding the variable.

Along the respondents, $45.1 \%$ educated and non-educated $66 \%$ agreed or strongly agreed that men try to control women by giving threat to bring second wife and it is associated significantly. On the contrary, $53.5 \%$ educated and $34 \%$ non-educated are disagreed or strongly disagreed toward the issue.

\subsection{Analysis of scale}

\section{Domestic violence against women related information}

After asking respondents to indicate their level of activity, there is a total score of each respondent by summing the value of each item. Suppose that, a respondent checked strongly agree in item 1(score5), undecided in item 2 (score3), agree in item3 (score4), disagree in item4 (score2), strongly disagree in item 5(score 1) and disagree in item 6(score2). This person's total score is $5+3+4+2+1+2=17$. Following illustration has been used to measurement -

1. Conflict between husband and wife in marital life is normal feature

2. Women are the main victims of domestic violence in patriarchal society

3. Men always do exercise their control on women in marital life

4. Many educated person oppress women in our society

5. Violence against women is in different form in natal house and in-laws house

6. Dowry related violence against women happened frequently in our society

The total result of the 125 respondents are given below in tabulated form-

\begin{tabular}{lrrr}
\hline \multicolumn{4}{c}{ Table 4:Level of perception about domestic violence } \\
\hline Response & Corresponding scores & Frequency & Percent \\
\hline Very low & $6-12$ & 10 & 8 \\
low & $13-18$ & 13 & 10.4 \\
medium & $19-24$ & 10 & 8 \\
\hline
\end{tabular}




\begin{tabular}{lrrr} 
high & $25-30$ & 45 & 36 \\
Very high & $31-30$ & 47 & 37.6 \\
Total & & 125 & 100 \\
\hline
\end{tabular}

From this table, it is clear that perception about violence against women is high among the respondents. Majority 37.6 and 36.6 percent respondents think that violence against women is very high and high in our society. Only $8 \%$ percent respondents have the perception that violence against women is very low in our society.

Now, for each item it is required to compute the Discriminative Power (DP) - which helps us to find the items that consistently distinguish who are high on the response continuum for those who are low.

\begin{tabular}{|c|c|c|c|c|c|c|c|c|c|c|}
\hline \multicolumn{11}{|c|}{ Table 5: Computing the Discriminative Power (DP) } \\
\hline Item- & Group & $\begin{array}{l}\text { Number } \\
\text { in Group }\end{array}$ & 1 & 2 & 3 & 4 & 5 & $\begin{array}{r}\text { Weighted } \\
\text { Total }\end{array}$ & $\begin{array}{r}\text { Weighted } \\
\text { Mean }\end{array}$ & $\mathrm{DP}(\mathrm{Q} 1-\mathrm{Q} 4)$ \\
\hline \multirow[b]{2}{*}{1} & High (top 25\%) & 31 & 0 & 5 & 6 & 9 & 11 & 119 & 3.84 & 1.9 \\
\hline & Low (bottom25\%) & 31 & 12 & 11 & 6 & 2 & 0 & 60 & 1.94 & \\
\hline \multirow[t]{2}{*}{2} & High (top 25\%) & 31 & 1 & 3 & 6 & 7 & 14 & 123 & 3.97 & 2.03 \\
\hline & Low (bottom $25 \%$ ) & 31 & 11 & 13 & 5 & 2 & 0 & 60 & 1.94 & \\
\hline \multirow[t]{2}{*}{3} & High (top 25\%) & 31 & 1 & 1 & 4 & 10 & 15 & 130 & 4.19 & 1.9 \\
\hline & Low (bottom25\%) & 31 & 13 & 6 & 5 & 4 & 3 & 71 & 2.29 & \\
\hline \multirow[t]{2}{*}{4} & High (top 25\%) & 31 & 1 & 5 & 7 & 8 & 10 & 114 & 3.68 & 2 \\
\hline & Low (bottom $25 \%$ ) & 31 & 17 & 10 & 2 & 1 & 1 & 52 & 1.68 & \\
\hline \multirow[t]{2}{*}{5} & High (top 25\%) & 31 & 2 & 3 & 7 & 10 & 9 & 114 & 3.68 & 1.71 \\
\hline & Low (bottom $25 \%$ ) & 31 & 10 & 16 & 2 & 2 & 1 & 61 & 1.97 & \\
\hline \multirow[t]{2}{*}{6} & High (top 25\%) & 31 & 3 & 3 & 5 & 9 & 11 & 115 & 3.71 & 1.45 \\
\hline & Low (bottom $25 \%$ ) & 31 & 8 & 12 & 7 & 3 & 1 & 70 & 2.26 & \\
\hline
\end{tabular}

Here, Weighted total=Score*no. who check that score. Weighted mean=Weighted total /no. in group. Discriminative Power=High (top 25\%)-low (bottom 25\%). (Nachmias and Nachmias; 1997, p-467).All of the above cited-tabulation clearly reveals the expected result. The calculation of Discriminative Power for each item represent that, the strongest items poses the highest discriminative power. In all cases, it is seen from the table that discriminative power varies to the variation of items.

\section{Hypothesis Testing}

\section{Hypothesis-1:}

$\mathrm{H}_{0}$ : There is no difference between years of schooling and the no. of domestic violence against women

$\mathrm{H}_{\mathrm{a}}$ : There is difference between years of schooling and the no. of domestic violence against women

\section{Hypothesis-2:}

$\mathrm{H}_{0}$ : There is no different between family income and the no. of domestic violence against women.

$\mathrm{H}_{\mathrm{a}}$ : There is different between family income and the no. of domestic violence against women.

\section{Hypothesis-3:}

$\mathrm{H}_{0}$ : There is no difference between Patriarchal attitude and the no. of domestic violence against women.

$\mathrm{H}_{\mathrm{a}}$ : There is difference between Patriarchal attitude and the no. of domestic violence against women

\section{Hypothesis-4:}

$\mathrm{H}_{0}$ : There is no difference between proper implementation of existing laws regarding punishment and the no. of domestic violence against women.

$\mathrm{H}_{\mathrm{a}}$ : There is difference between proper implementation of existing laws regarding punishment and the no. of domestic violence against women.

\section{Hypothesis-5:}

$\mathrm{H}_{\mathrm{o}}$ : There is no difference between religious values and the no. of domestic violence against women.

$\mathrm{H}_{\mathrm{a}}$ : There is difference between religious values and the no. of domestic violence against women.

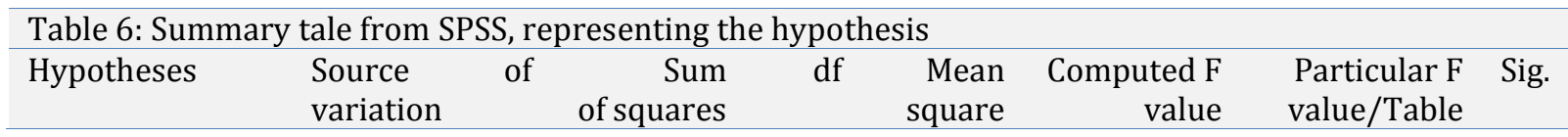




\begin{tabular}{|c|c|c|c|c|c|c|c|}
\hline \multirow{2}{*}{ Hypothesis-1: } & & & & & \multicolumn{3}{|c|}{ value } \\
\hline & $\begin{array}{l}\text { Between } \\
\text { groups } \\
\text { Within groups } \\
\text { Total }\end{array}$ & $\begin{array}{r}420.499 \\
95.949 \\
516.448\end{array}$ & $\begin{array}{r}23 \\
102\end{array}$ & $\begin{array}{r}32.346 \\
.940\end{array}$ & 34.411 & 2.26 & .05 \\
\hline Hypothesis-2: & $\begin{array}{l}\text { Between } \\
\text { groups } \\
\text { Within groups } \\
\text { Total }\end{array}$ & $\begin{array}{r}911.462 \\
330.314 \\
1241.776\end{array}$ & $\begin{array}{r}125 \\
9 \\
116\end{array}$ & $\begin{array}{r}101.274 \\
2.848\end{array}$ & 35.560 & 2.76 & .05 \\
\hline Hypothesis-3: & $\begin{array}{l}\text { Between } \\
\text { groups } \\
\text { Within groups } \\
\text { Total }\end{array}$ & $\begin{array}{r}812.373 \\
439.554 \\
1251.1927\end{array}$ & $\begin{array}{r}125 \\
25 \\
100\end{array}$ & $\begin{array}{r}32.495 \\
4.395\end{array}$ & 7.394 & 1.77 & .05 \\
\hline Hypothesis-4: & $\begin{array}{l}\text { Between } \\
\text { groups } \\
\text { Within groups } \\
\text { Total }\end{array}$ & $\begin{array}{l}398.172 \\
125.951 \\
524.123\end{array}$ & $\begin{array}{r}125 \\
5 \\
120\end{array}$ & $\begin{array}{r}79.634 \\
1.050\end{array}$ & 75.84 & 4.40 & .05 \\
\hline Hypothesis-5: & $\begin{array}{l}\text { Between } \\
\text { groups } \\
\text { Within groups } \\
\text { Total }\end{array}$ & $\begin{array}{r}911.462 \\
330.314 \\
1241.776\end{array}$ & $\begin{array}{r}125 \\
9 \\
116\end{array}$ & $\begin{array}{r}101.274 \\
2.848\end{array}$ & 35.560 & 2.76 & .05 \\
\hline
\end{tabular}

Statistics of the above table reveals that between group variance is larger than the within group variance, therefore, the null hypothesis can be rejected. As we can see that all the particular F value /table value is smaller than all the computed $\mathrm{F}$ value, therefore, all the alternative hypotheses can be accepted by rejecting all the null hypotheses. So, years of schooling, family income, patriarchal attitude, existing laws regarding punishment and religious values are not related to no. of domestic violence against women.

\subsection{Comparative assessment}

Educated class think domestic violence means anything happens forcefully due to dominating mentality in the family. It has different forms such as physical, mental and verbal but at present mental and verbal abuse are mostly seen in the family. One educated respondent said "Any type of verbal abuse, physical and mental torture, trying to undermine technically are called violence. As a traditional society, Husband try to dominated wife. They try to control them in many ways. As a result, a conflicting situation always exists between husband and wife. Non educated class said that Domestic violence means biting wife husband and vice versa, wants dowry, force to intercourse frequently, denies the opinion of the wife, does not bear clothes of the wife etc. According to the violence occurs, if wife do not satisfy the husband sexual satisfaction. In this view, frequency of the sexual intercourse also abuse violence. Wives are betting while they refuse to sex.

Educated class think that domestic violence may happen for various reasons such as poverty, lack of women's education, social system, patriarchal mentality etc. many kinds of problem arise in family because of economic crisis. If the family fails to solve this economic crisis, then family members will become mentally disappointed and hence the result is domestic violence. One respondent said "Economy is the sole reason for domestic violence as it happens frequently in lower class families. Besides, lack of mutual understanding dissimilitude opinion etc. is important reasons behind it.

Non educated class mentioned that economy is the main problem for the domestic violence. If a wife is not educated and economically not solvent, she is totally depending on his husband. She has been tortured by her husband but she didn't file any case against it.

Through this study it has been tried to explore something new about domestic violence. From the present study it can be said that women are the main victims of domestic violence. There exist various reasons. One of them is the lack of education of women and also men. From the study we will get the evidence of it. The study report shows that only $1.4 \%$ male respondents have $\mathrm{PhD}$ holder wives where as $11.8 \%$ female respondents have PhD 
holder husbands. Again, 8.1\% male respondents have HSC completed wives whereas no female respondents have HSC completed husbands. So from educational point of view women's position is backward that that of men. There is a significant difference between educated class view regarding violence and that of non-educated class. Only 10\% educated respondents told that violence means physical, mental and verbal torture whereas only 3.9\% non-educated respondents think so. So, it can be said that non-educated themselves do not consider verbal abuse is also violence as it humiliates humanity. A gain, 31.4\% non-educated think that the main reason for women suppression is that it is in our society it is considered as a normal matter where the educated percentage is $21.6 \%$.

\subsection{Conclusion and suggestions for future research}

In the present time, violence against women is not a new concept. It may be seen either in the family environment or outside of it. In our country, in the family environment women face various types of violence such as physical and mental torture, verbal abuse etc. but still now maximum people both educated and noneducated don't consider verbal abuse as a violence rather they think that physical and mental torture are included in violence. Through this study, it is revealed that verbal abuse is also violence against women and particular law should be made regarding it. In the study area, most of the respondents view those main causes of domestic violence. Moreover, because of tradition and custom, lack of education and income violence is occurred in the family environment. So, Govt. has to take proper step to empower women by making them educated and engaging them in income generating activities. Besides, as maximum numbers of offences occur because of poverty, it has to be alleviated from the society.

\section{References}

Adams, A. E., Sullivan, C. M., Bybee, D., \&Greeson, M. R. (2008). Development of the scale of economic abuse. Violence against Women,14(5), 563-588. Doi:10.1177/1077801208315529

Akanda, L., \& Shamim, I. (1985). Women and violence: a comparative study of rural and urban violence against women in Bangladesh. Retrieved from: http://www.popline.org/node/381521

Cochran, W. G. (1997). Sampling Techniques", third edition, john Wiley \& Sons, New York.

Halim, M. A. (1995). Women's Crisis Within Family in Bangladesh. Bangladesh Society for the Enforcement of Human Rights.

Kay, M., (2008). Domestic Violence Escalates Nationwide in Light of the Economy, Survivors Struggle to Find Jobs.

Mannan, M.A. (2003). Women's Security Paper-Neither Freedom Nor Choice: A Study of Wife Abuse in Rural Bangladesh", Forum on Women in Security and International Affairs, Dhaka, 2003.

Nachmias, D., \& Nachmias, C. (1976). Research methods in the social sciences. Arnold, New York

Naved, R. T., \&Persson, L. Å. (2005). Factors associated with spousal physical violence against women in Bangladesh. Studies in family planning,36(4), 289-300. DOI: 10.1111/j.1728-4465.2005.00071.x

Naved, R. T., \& Persson, L. A. (2010). Dowry and spousal physical violence against women in Bangladesh. Journal of family issues, 31(6), 830-856.doi:10.1177/0192513X09357554.

Jahan, R., \& Islam, M. (1997). Violence against women in Bangladesh: analysis and action. Women for Women and South Asian Association for Women Studies.

Parvin, K., Sultana, N., \&Naved, R. T. (2016). Disclosure and help seeking behavior of women exposed to physical spousal violence in Dhaka slums.BMC public health, 16(1), 1. http://dx.doi.org/10.1186/s12889-0163060-7

Sahay, S. (1998). Women and Empowerment-Approaches and Strategies, first edition, Discovery Publishing House, New Delhi.

Vander Ende, K. E., Sibley, L. M., Cheong, Y. F., Naved, R. T., \&Yount, K. M. (2015). Community Economic Status and Intimate Partner Violence Against Women in Bangladesh Compositional or Contextual Effects? Violence against women, 21(6), 679-699. doi: 10.1177/1077801215576938. 